\title{
Agaricus subrufescens: substratum nitrogen concentration and mycelial extraction method on antitumor activity
}

\author{
MÍRIA B.D. BERTÉLI ${ }^{1}$, ANA D. LOPES ${ }^{1}$, ITARUÃ M. COLLA ${ }^{1}$, GIANI A. LINDE ${ }^{1}$ and NELSON B. COLAUTO ${ }^{1}$ \\ ${ }^{1}$ Postgraduate Program in Biotechnolgy Applied to Agriculture, Universidade Paranaense, \\ Praça Mascarenhas de Moraes, 4282, 87502-210 Umuarama, PR, Brazil \\ Manuscript received on March 30, 2016; accepted for publication on June 24, 2016
}

\begin{abstract}
Antitumor activity of Agaricus subrufescens has been shown on vegetative mycelium and basidiocarp. However, few studies have assessed the effect of $A$. subrufescens cultivation conditions and extraction methods on antitumor activity. This study evaluated the effect of nitrogen concentration on the cultivation medium of $A$. subrufescens and the extraction method of mycelial antineoplastic actives against sarcoma 180 cells implanted in mice. Two nitrogen sources (isolated soybean protein and $\mathrm{NaNO}_{3}$ ) and 10 nitrogen concentrations $(0.25$ to $8.0 \mathrm{~g} / \mathrm{L})$ were used. Dried mycelium extract was obtained by hot water infusion (1:10 mass:volume; $\left.90^{\circ} \mathrm{C}\right)$ or by aqueous mixture (1:10 mass:volume, ambient temperature) in ultrapure water. The doses were administered daily by gavage to mice implanted with sarcoma 180 cells. Isolated soy protein is more efficient to mycelial biomass production than $\mathrm{NaNO}_{3}$. The mycelial biomass production increases when the cultivation medium is added with high nitrogen concentrations as well as the splenic index and the antitumor activity of the moistened mycelial powder. Hot water extract is more effective than the moistened mycelial powder to reduce tumor. The antitumor activity of hot water mycelial extract is similar to the one of basidiocarps, presenting lower metabolic demand on the spleen, keeping blood parameters normal and promoting animal wellness.
\end{abstract}

Key words: Agaricus blazei, Agaricus brasiliensis, Antineoplastic, Basidiocarp, Medicinal mushrooms, Mycelium.

\section{INTRODUCTION}

Most of edible mushrooms are consumed because of their culinary and/or therapeutic properties (Wasser 2011). Among them, Agaricus subrufescens Peck (Kerrigan 2005), mostly referred as Agaricus blazei Murrill sensu Heinemann (Colauto and Linde 2012) and Agaricus brasiliensis Wasser et al. (Wasser et al. 2002), is cultivated worldwide, used as functional food, or utilized in alternative

Correspondence to: Nelson Barros Colauto

E-mail: nbc@unipar.br medicine (Colauto and Linde 2012). It has been reported that $A$. subrufescens basidiocarps present therapeutic uses due to their antitumor (Mourão et al. 2009, Jumes et al. 2010), immunomodulatory, antimetastatic, antimutagenic (Firenzuoli et al. 2008), anti-inflammatory (Mourão et al. 2011a), antioxidant (Mourão et al. 2011b) properties to name but a few. Moreover, it has been used to improve an individual's general health, reducing the effects of conventional antineoplastic treatments (Ramberg et al. 2010). 
It is still quite expensive to grow basidiocarps in some countries, so a relatively cheap and stable source for commercial purpose has still been sought (Firenzuoli et al. 2008). Vegetative mycelial cultivation has some advantages over basidiocarps such as shorter time and lower production cost besides a greater control of the productive process, reducing contaminant risks. Fan et al. (2003) reported mycelial submerged cultivation of $A$. subrufescens using mostly glucose-peptone-yeast extract medium. However, few studies investigated alternative and cheap sources and concentrations of nitrogen in liquid culture medium on antitumor activity of $A$. subrufescens mycelia (Bertéli et al. 2014).

Consumption of $A$. subrufescens is varied and can be found from fresh to dried fruiting bodies, although it is mostly prepared as tea (hot water extract) or taken as capsules (ground dried) for therapeutic purposes (Colauto and Linde 2012). However, extraction and cultivation methods affect biological activity of $A$. subrufescens against sarcoma 180 (Bertéli et al. 2014) and Walker-256 (Jumes et al. 2010) tumors. Thus, the objective of this study was to evaluate the effect of nitrogen concentration on the cultivation medium of $A$. subrufescens and the extraction method of mycelial antineoplastic actives on sarcoma 180 cells implanted in mice.

\section{MATERIALS AND METHODS}

Strain U6-15 of $A$. subrufescens from the culture collection of the Laboratory of Molecular Biology of Paranaense University was used. The strain was cryopreserved at $-70{ }^{\circ} \mathrm{C}$ and recovered in 20 $\mathrm{g} / \mathrm{L}$ malt agar extract (MAE) at $25^{\circ} \mathrm{C}$ in the dark (Colauto et al. 2012).

\section{MYCELIAL BIOMASS PRODUCTION}

The following procedures described by Bertéli et al. (2014) were used to produced inoculum and mycelial biomass. Two $6 \mathrm{~mm}$ diameter MAE discs containing mycelium, which was used as inoculum, were transferred to $15 \mathrm{~mL}$ Falcon tubes containing previously hydrated wheat grains (1:10), cooked at $90{ }^{\circ} \mathrm{C}$ for $45 \mathrm{~min}$, and autoclaved for $1 \mathrm{~h}$ and $30 \mathrm{~min}$ at $121{ }^{\circ} \mathrm{C}$. The material was incubated in the dark at $25^{\circ} \mathrm{C}$ for 15 days. For the production of mycelial biomass, liquid Pontecorvo minimum medium consisting of $1.5 \mathrm{~g} / \mathrm{L} \mathrm{KH}_{2}-\mathrm{PO}_{4}, 0.5 \mathrm{~g} / \mathrm{L} \mathrm{KCl}, 1.0232$ $\mathrm{g} / \mathrm{L} \mathrm{MgSO}_{4} 7 \mathrm{H}_{2} \mathrm{O}, 0.010 \mathrm{~g} / \mathrm{L} \mathrm{Fe}_{2} \mathrm{SO}_{4} 7 \mathrm{H}_{2} \mathrm{O}, 0.0178$ $\mathrm{g} / \mathrm{L} \mathrm{ZnSO}_{4} 7 \mathrm{H}_{2} \mathrm{O}$, and $10.0 \mathrm{~g} / \mathrm{L}$ glucose was used (Pontecorvo et al. 1953). Isolated soy protein (ISP) from Solae Company (97\% purity) or $\mathrm{NaNO}_{3}$ was added to Pontecorvo medium to obtain nitrogen concentrations from 0.25 to $8.0 \mathrm{~g} / \mathrm{L}$. ISP was previously dried at $105{ }^{\circ} \mathrm{C}$ until constant mass to determine moisture; total nitrogen was determined by Kjeldahl's method. The cultivation media (30 mL) were transferred to $125 \mathrm{~mL}$ Erlenmeyer flasks and autoclaved at $121{ }^{\circ} \mathrm{C}$ for $20 \mathrm{~min}$. Each Erlenmeyer flask with three colonized wheat grains was kept at $28{ }^{\circ} \mathrm{C}$ in the dark without agitation for 22 days.

After mycelial growth, wheat grains were removed and mycelial biomass was separated by centrifugation at $1700 \mathrm{~g}$ at $4{ }^{\circ} \mathrm{C}$ for $15 \mathrm{~min}$. The supernatant was discarded and the precipitate was washed four times with $30 \mathrm{~mL}$ of ultrapure water. The obtained mycelial biomass was dehydrated in an oven at $60{ }^{\circ} \mathrm{C}$ until constant mass, ground in a mortar with a pestle until powder, and frozen at $-70{ }^{\circ} \mathrm{C}$. The average and standard deviation of six replicates were calculated for each treatment.

\section{MYCELIAL BIOMASS EXTRACTION}

Mycelial biomass extraction was prepared by mixing dried mycelial powder and ultrapure water (1:10 mass:volume) in a capped amber glass flask at $90{ }^{\circ} \mathrm{C}$ for $12 \mathrm{~h}$. It was filtered in a $14 \mu \mathrm{m}$ diameter pore filter and frozen at $-70^{\circ} \mathrm{C}$. This process aimed to simulate tea preparation. Total solid concentration $(\mathrm{mg} / \mathrm{mL})$ of hot water mycelial extract was determined by drying part of each extract at $60^{\circ} \mathrm{C}$ 
until constant mass. Moistened mycelial powder was prepared by mixing dried mycelial powder and ultrapure water (1:10 mass:volume) at room temperature just before administration to animals. This process aimed to simulate the use of capsules with mycelial powder. Water addition made administration by gavage easier to the animal. For control, $9 \mathrm{~g} / \mathrm{L}$ saline solution (SSC) was used. The treatment codes are shown in Table I.

\section{ANIMAL EXPERIMENT}

All procedures were approved by the Committee of Ethics in Research involving Animal Experimentation (CEPEEA) of the Paranaense University. Thirty-two non-isogenic female Swiss mice of 29-32 $\mathrm{g}$ and with 42 days of age were used. The animals were adapted to the experimental place for seven days and then kept in the same room in plastic boxes with alternated $12 \mathrm{~h}$ light management at $24 \pm 2{ }^{\circ} \mathrm{C}$. Commercial feed and water were provided ad libitum. The ascitic form of sarcoma 180 (S180) was maintained in mice by intraperitoneal inoculation. Seven-day-old S180 ascitic cells $\left(5 \times 10^{6}\right.$ cells $)$ were transplanted subcutaneously into the cervical-dorsal region of the mice (Shirai et al. 1991). After seven days of implantation of S180 cells, the animals were randomly separated in four treatments with eight replicates each $(n=8)$. Each animal received 0.1 $\mathrm{mL}$ of hot water mycelial extract or moistened mycelial powder at a concentration of $140 \mathrm{mg} / \mathrm{kg}$ of animal by gavage (Jumes et al. 2010). The control group received $0.1 \mathrm{~mL}$ of $9 \mathrm{~g} / \mathrm{L}$ saline solution by gavage daily (Ponte et al. 2012). Thirty days after the beginning of the treatments, the animals were anaesthetized with Halothane ${ }^{\circledR}(50 \mathrm{mg} / \mathrm{kg}$ of animal) and $1 \mathrm{~mL}$ of blood was collected from the orbital plexus of each animal using glass capillaries embedded in $100 \mathrm{~g} / \mathrm{L}$ of 2-( $\{2$-[bis(carboxymethyl) amino]ethyl (carboxymethyl)amino) acetic acid (EDTA) (Thrall et al. 2012). After that, animals were euthanized by overdose of the anesthetic Halothane $^{\circledR}(150 \mathrm{mg} / \mathrm{kg}$ of animal). Spleen and tumoral mass were removed and measured by analytical scale. The tumor inhibition rate was calculated considering as $100 \%$ the tumor mass of the control. The splenic index was calculated considering the spleen mass per animal body mass $(\mathrm{mg} / \mathrm{g})$ (Shirai et al. 1991).

Blood count was assessed in a Neubauer chamber to verify the total number of erythrocytes using Hayem liquid ( $2 \mathrm{~mL}$ per $10 \mu \mathrm{L}$ of blood), and the total number of leukocytes was calculated using Turk liquid ( $400 \mu \mathrm{L}$ per $20 \mu \mathrm{L}$ of blood). Evaluation of cell morphology and differential cell counting were performed by preparing blood smear by May Grunwald-Giemsa's method (Meyer et al. 1992). Comparison among groups was performed by variance analysis, and significant differences were determined by Scott-Knott's test $(\mathrm{P} \leq 0.01)$.

\section{RESULTS}

\section{MYCELIAL BIOMASS PRODUCTION}

Mycelial biomass production varied regarding the source as well as the nitrogen concentration of the utilized cultivation medium. The mycelial biomass production was reduced when the fungus

TABLE I

Treatment codes.

\begin{tabular}{ccc}
\hline Treatment code & $\begin{array}{c}\text { Nitrogen concentration of isolated soy protein in } \\
\text { culture medium }(\mathbf{g} / \mathbf{L})\end{array}$ & Dehydrated mycelial preparation/control \\
\hline SM05 & 0.5 & Moistened mycelial powder \\
SM5 & 5.0 & Moistened mycelial powder \\
SE5 & 5.0 & Hot water mycelial extract \\
SSC & Saline solution $(9 \mathrm{~g} / \mathrm{L})$ & Control \\
\hline
\end{tabular}


was cultivated in medium supplemented with nonprotein nitrogen source of $\mathrm{NaNO}_{3}$, not exceeding $2.9 \mathrm{mg} / \mathrm{mL}$. Regarding the protein nitrogen of ISP, the maximum mycelial biomass production was $19.4 \mathrm{mg} / \mathrm{mL}$, which is equivalent to 6.7 times the production with $\mathrm{NaNO}_{3}$ (Figure 1). Thus, ISP was selected as the nitrogen source for subsequent experiments on antineoplastic activity.

An inhibition of 46 to $90 \%(\mathrm{P} \leq 0.01)$ of the tumoral mass (Figure 2) and a lower splenic index of 36 to $76 \%$ (Figure 3) were observed in the animals treated with moistened mycelial powder from mycelium cultivated with $0.5 \mathrm{~g} / \mathrm{L}$ (SM05) or $5.0 \mathrm{~g} / \mathrm{L}$ (SM5) of protein nitrogen from ISP and hot water mycelial extract from mycelium cultivated with $5.0 \mathrm{~g} / \mathrm{L}$ (SE5) of protein nitrogen from ISP (Figure 1).

The highest nitrogen concentration in the cultivation medium of moistened mycelial powder
(SM5) resulted in inhibition 1.7 times higher (P $\leq 0.01$ ) than SM05 (Figure 2), and made evident that the highest nitrogen concentration of ISP in the cultivation medium increased the tumor inhibition capacity. For hot water mycelial extract (SE5), tumor inhibition was 1.2 times higher $(\mathrm{P} \leq 0.01)$ than moistened mycelial powder (SM5) (Figure 2). In general, treatment SE5 was the most effective for tumor inhibition, presenting more than $90 \%$ of inhibition when compared to the other treatments and the control (Figure 2).

The splenic index was lower $(\mathrm{P} \leq 0.01)$ for hot water mycelial extract (SE5) with $7.82 \mathrm{mg} / \mathrm{g}$, followed by moistened mycelial powder (SM5) with $13.05 \mathrm{mg} / \mathrm{g}$ and moistened mycelial powder (SM05) with $20.72 \mathrm{mg} / \mathrm{g}$ compared to the control with $32.64 \mathrm{mg} / \mathrm{g}$ (Figure 3). This indicates that SE5 resulted in smaller metabolic demand from the spleen.

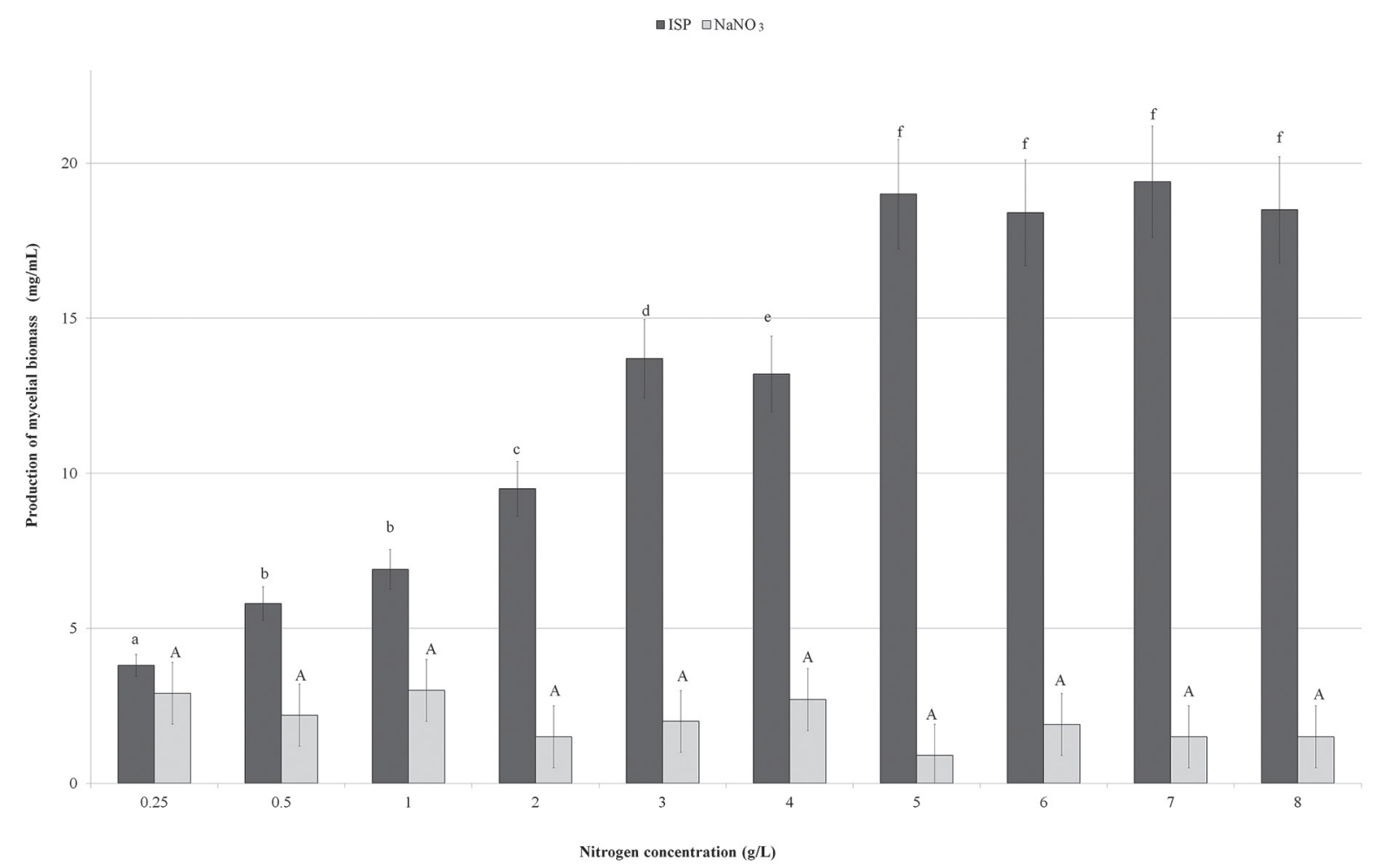

Figure 1 - Mycelial biomass production (mg/mL) of Agaricus subrufescens obtained in minimum liquid Pontecorvo medium at different concentrations $\left(\mathrm{g} / \mathrm{L}\right.$ ) of isolated soy protein (ISP) and $\mathrm{NaNO}_{3}$ after 22 days, without agitation, at $28^{\circ} \mathrm{C}$. 


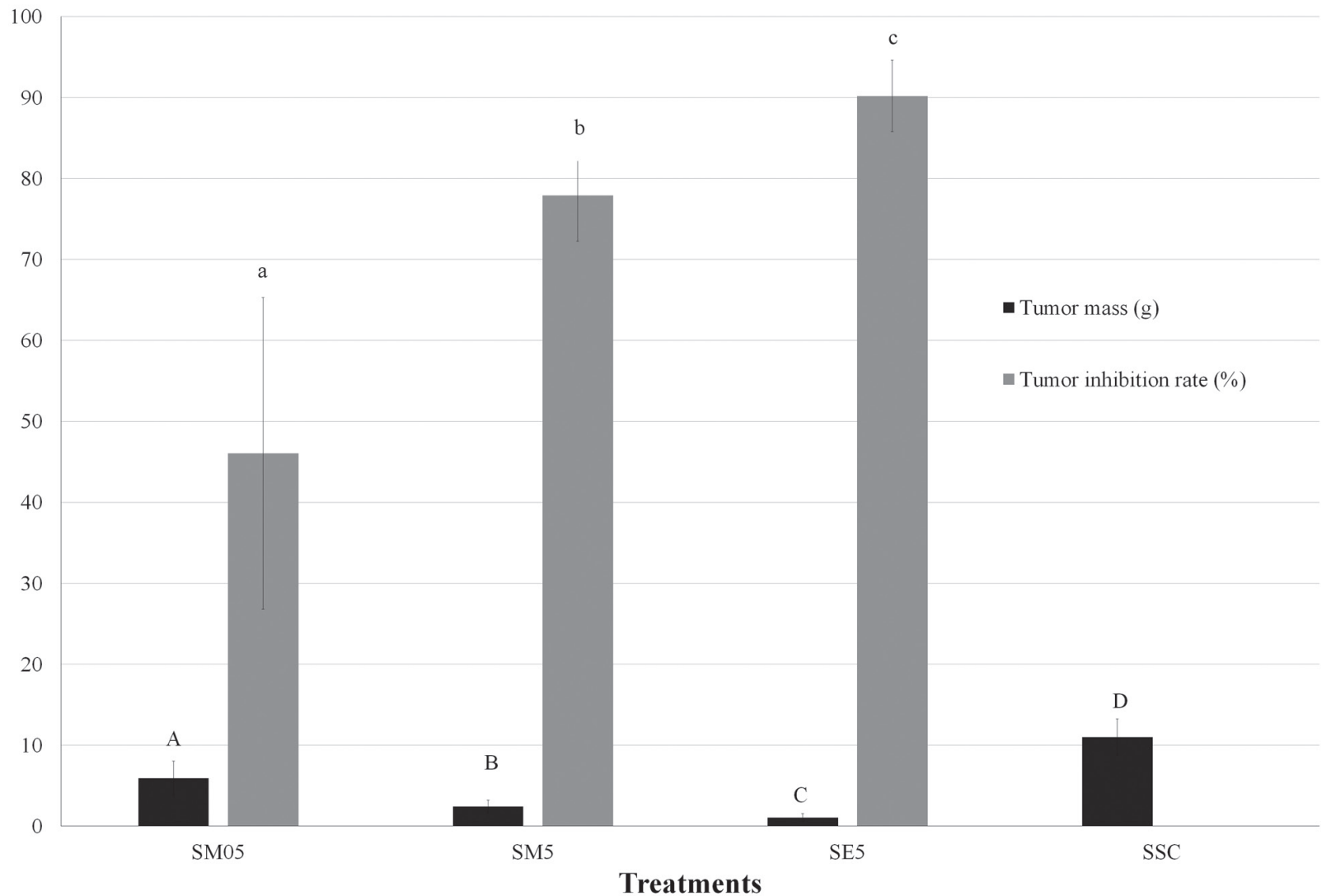

Figure 2 - Inhibition of sarcoma 180 tumor mass implanted in female Swiss mice according to treatments (Table I). Different letters show that the treatments statistically and significantly differed from each other according to Scott-Knott's test $(\mathrm{P} \leq 0.01)$.

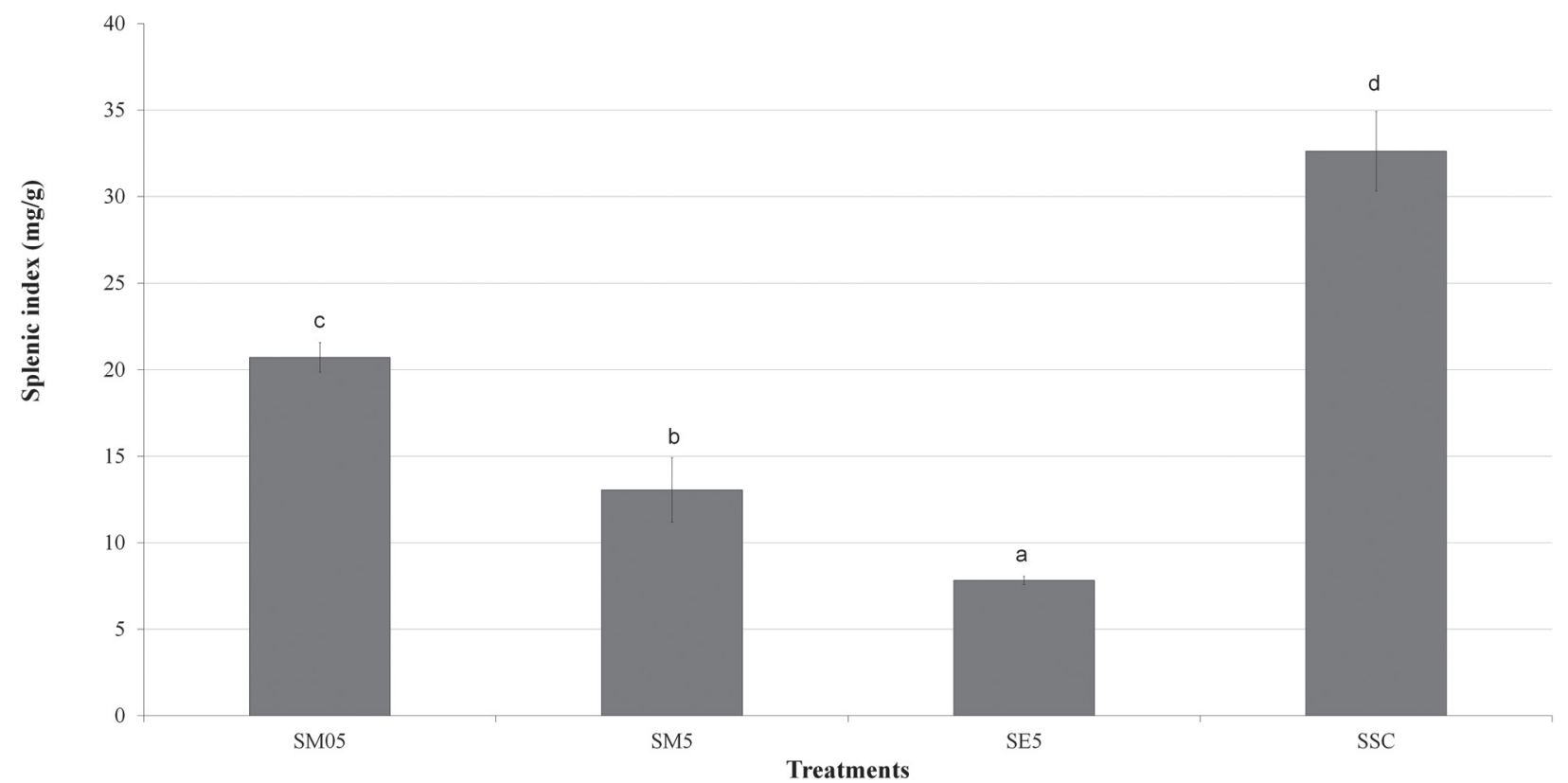

Figure 3 - Splenic index of female Swiss mice's spleen implanted with sarcoma 180 according to treatments (Table I). Different letters show that the treatments statistically and significantly differed from each other according to Scott-Knott's test $(\mathrm{P} \leq 0.01)$. 
For blood cells, the values of treatment SE5 were the only ones within normality range (Table II). All other treatments and the control were under the normality indexes presented leukopenia with the lowest $(\mathrm{P} \leq 0.01)$ values of total expected leukocytes for these animals (Table II). Lymphocytes, which are important to fight tumor cells, presented values closer to normality for all treatments, except for the control (Table II). However, there was greater stimulation of lymphocyte amount for SE5 and SM5 (Table II), which had higher nitrogen amount in the cultivation medium (Figure 1). Animals treated with SE5 and SM5 showed neutrophils within normality range, an essential part of the innate immune system, whereas SM05 and the control were above it (Table II).

\section{DISCUSSION}

Submerged cultivation of A blazei yielded 9.12 $\mathrm{mg} / \mathrm{mL}$ of mycelial biomass when yeast extract was used as nitrogen source (Hamedi et al. 2007), $10.83 \mathrm{mg} / \mathrm{mL}$ when malt extract was used (Lin and Yang 2006) and $9.85 \mathrm{mg} / \mathrm{mL}$ when soytone peptone was used (Kim et al. 2004). Bertéli et al. (2014) reported A. blazei mycelia of $19.6 \mathrm{mg} / \mathrm{mL}$ when ISP was used as nitrogen source in submerged cultivation. Hamedi et al. (2007) verified A. blazei mycelial production utilizing non-protein sources such as ammonium oxalate, potassium nitrate, ammonium sulfate, ammonium chloride and urea with maximum yield of $1 \mathrm{mg} / \mathrm{mL}$. In our study, the maximum mycelial production was $19.4 \mathrm{mg} / \mathrm{mL}$ with ISP and $2.9 \mathrm{mg} / \mathrm{mL}$ with $\mathrm{NaNO}_{3}$. These results indicate that protein nitrogen sources as ISP are the best source to produce mycelia for this species in submerged cultivation than non-protein nitrogen source.

In our study, the higher nitrogen concentration in the cultivation medium increased mycelial biomass production up to $19.4 \mathrm{mg} / \mathrm{mL}$ with ISP. Also, it increased the antioneoplastic activity for moistened mycelial powder SM5 when compared to SM05 (Figure 2). Nitrogen protein sources such as ISP can be hydrolyzed by fungal proteases with quick release of amino acids that are readily assimilated for protein synthesis, whereas nonprotein sources like $\mathrm{NaNO}_{3}$ need the action of nitrate permease for their intracellular transport (Griffin 1994). Therefore, when compared to ISP, a greater number of metabolic steps are needed for nitrate protein production which explains the fungus difficulty to grow with $\mathrm{NaNO}_{3}$. The active principles responsible for antitumor activity are mainly beta glucans (Firenzuoli et al. 2008) which can be bonded to proteins (Adams 2004). Zhang et al. (2007) report that the presence of protein attached to the cell wall increases the antineoplastic activity of the fungus. It suggests that the culture medium formulation can affect mycelial biomass yield, mycelial chemical components and, therefore, enhance antineoplastic activity on S180. However, Bertéli et al. (2014) did not find

TABLE II

Hemogram of female Swiss mice implanted with sarcoma 180 cells after 30 days.

\begin{tabular}{ccccccc}
\hline Treatment code & $\mathbf{H e}(\mathbf{1 0} / \boldsymbol{\mu L})$ & $\mathbf{H b}(\mathbf{g} / \mathbf{d L})$ & $\mathbf{H t}(\boldsymbol{\%})$ & $\mathbf{L c}\left(\mathbf{1 0} \mathbf{3}^{\mathbf{3}} / \boldsymbol{\mu L}\right)$ & $\mathbf{N t}(\%)$ & $\mathbf{L f}(\%)$ \\
\hline SM05 & $3.7 \pm 1.0^{\mathrm{b}}$ & $8.0 \pm 1.3^{\mathrm{bc}}$ & $23.7 \pm 3.9^{\mathrm{b}}$ & $3.2 \pm 1.3^{\mathrm{b}}$ & $55.7 \pm 14.7^{\mathrm{b}}$ & $43.2 \pm 4.6^{\mathrm{b}}$ \\
SM5 & $3.4 \pm 0.5^{\mathrm{b}}$ & $8.6 \pm 0.5^{\mathrm{b}}$ & $26.0 \pm 2.6^{\mathrm{b}}$ & $2.9 \pm 0.3^{\mathrm{b}}$ & $16.7 \pm 6.0^{\mathrm{c}}$ & $83.3 \pm 6.0^{\mathrm{a}}$ \\
SE5 & $6.7 \pm 1.3^{\mathrm{a}}$ & $11.7 \pm 1.0^{\mathrm{a}}$ & $35.1 \pm 1.4^{\mathrm{a}}$ & $7.0 \pm 1.3^{\mathrm{a}}$ & $14.8 \pm 4.6^{\mathrm{c}}$ & $78.1 \pm 4.6^{\mathrm{a}}$ \\
SSC & $3.8 \pm 0.6^{\mathrm{b}}$ & $72.0 \pm 1.4^{\mathrm{c}}$ & $21.7 \pm 3.5^{\mathrm{b}}$ & $3.0 \pm 1.2^{\mathrm{b}}$ & $74.7 \pm 8.8^{\mathrm{a}}$ & $25.3 \pm 8.8^{\mathrm{c}}$ \\
Reference values & 6.5 to 10.1 & 10 to 16 & 32 to 48 & 6.3 to 10.0 & 15 to 20 & 45 to 80 \\
\hline
\end{tabular}

${ }^{*}$ Treatment code described in Table $1 . \mathrm{He}=$ erythrocyte, $\mathrm{Hb}=$ hemoglobin, $\mathrm{Ht}=$ hematocrit, $\mathrm{Lc}=$ total leukocyte, $\mathrm{Nt}=$ neutrophil (segmented), Lf = lymphocyte. Reference values = values within the normal range for mice (Thrall, 2007). Different letters indicate statistically significant difference among the treatments according to Scott-Knott's test $(\mathrm{P} \leq 0.01)$. 
significant differences in the antitumor activity of moistened mycelial powder with a different strain of A. blazei on S180 in a study utilizing the same nitrogen concentrations in the cultivation medium.

On the other hand, hot water mycelial extract SE5 instead of moistened mycelial powder had higher tumor reduction (90\%) with lower metabolic demand on spleen and maintenance of normal blood parameters (Table II, Figures 2 and 3 ). Bertéli et al. (2014) reported similar results of $82-93 \%$ tumor reduction for hot water mycelial extract of $A$. blazei and 17-65\% for moistened mycelial powder. Hot water mycelial extract probably allowed a greater release of bioactive substances than moistened mycelial powder. For the moistened mycelial powder, the release of bioactive compounds depended exclusively on the animal's digestive process, which was a limiting factor because it depends on numerous variables inherent to the animals. Our results suggest that the immunoprotective compounds of mycelia can be more accessible after hot water mycelial extract. Thus, the utilization of hot water mycelial extracts enhances the antineoplasic activity of this species against S180 and improves the animal's general health.

However, Jumes et al. (2010) reported no difference between hot water mycelial extract and moistened mycelial powder of $A$. brasiliensis against Walker-256 tumor with mass inhibition ranging from 85 to $92 \%$ in rats. Although it is a fungus of the same species, these results differ from the ones in our study; nevertheless, the tumor and animal models were different, making any comparison between the studies difficult. On the other hand, Kim et al. (2004) reported that hot water mycelial extracts of $A$. blazei showed significant antitumor activity against $\mathrm{S} 180$ in mice with 96\% tumor inhibition. Bertéli et al. (2014) reported that $A$. blazei mycelial hot water extract presented $92.60 \%$ of tumor inhibition against S180 in mice. Mourão et al. (2009) reported that there was a tumor inhibition of $92 \%$ against S180 utilizing hot water mycelial extract of basidiocarps from $A$. blazei. This indicates that the mycelium as well as the basidiocarp of $A$. blazei has the same antineoplastic activity. However, Mizuno et al. (1999) reported that antitumor activity on S180 of hot water soluble fraction polysaccharides of A. blazei mycelium did not react with antibodies such as antitumor polysaccharides from $A$. blazei mushroom indicating a smaller antineoplastic activity of the mycelium. This suggests that the antineoplastic activity can depend on the utilized substrate, strain, tumor model type and extraction method of the fungus.

However, future studies are necessary to clear out if the biocompounds obtained by different extraction methods and the therapeutic potential of each extraction method, avoiding subutilization of medicinal properties by the industry and the consumers.

Moreover, the referred literature and the results reported in our study indicate that the commercialization of $A$. subrufescens has to be followed up by the quality control of the utilized strain, substrate formulation and extraction method for the desired biological activity.

\section{CONCLUSIONS}

Isolated soy protein instead of $\mathrm{NaNO}_{3}$ is the best nitrogen source for mycelial biomass production of Agaricus subrufescens in submerged cultivation. The higher nitrogen concentration in the cultivation medium improves the mycelial biomass production, splenic index and antitumor activity of moistened mycelial powder. However, hot water mycelial extract (tea simulation) is more effective than moistened mycelial powder (capsule simulation) against sarcoma 180 tumor reduction. The antitumor activity of hot water mycelial extract is the same as the one of basidiocarps, has smaller metabolic demand of the spleen and keeps normal blood parameters, promoting animal's wellness. 


\section{ACKNOWLEDGMENTS}

The authors thank the Paranaense University, the Postgraduate Program in Biotechnology Applied to Agriculture of the Paranaense University and Coordenação de Aperfeiçoamento de Pessoal de Nível Superior (CAPES) for the financial support and the fellowship.

\section{REFERENCES}

ADAMS DJ. 2004. Fungal cell wall chitinases and glucanases. Microbiology 150: 2029-2035.

BERTÉLI MBD, UMEO SH, BERTÉLI A, VALLE JS, LINDE GA AND COLAUTO NB. 2014. Mycelial antineoplastic activity of Agaricus blazei. World J Microbiol Biotechnol 30: 2307-2313.

COLAUTO NB, CORDEIRO FA, GEROMINI KVN, LIMA TG, LOPES AD, NUNES RAR, RORATTO FB, TANAKA HS, ZAGHI LL AND LINDE GA. 2012. Viability of Agaricus blazei after long-term cryopreservation. Ann Microbiol 62: 871-876.

COLAUTO NB AND LINDE GA. 2012. Avances sobre el cultivo de "cogumelo-do-sol" em Brasil. In: SÁNCHEZ JE AND MATA G (Eds), Hongos comestibles y medicinales in Iberoamérica: investigación y desarrollo en un entorno multicultural, Tapachula: Colegio de la Frontera Sur, Tapachula, Mexico, p. 53-67.

FAN L, SOCCOL AT, PANDEY A, GERMANO S, RAU R AND PEDROSO RS. 2003. Production of polysaccharide by culinary-medicinal mushroom Agaricus brasiliensis $\mathrm{S}$. Wasser et al. LPB 03 (Agaricomycetideae) in submerged fermentation and its antitumor effect. Int J Med Mushrooms 5: 17-24.

FIRENZUOLI F, GORI L AND LOMBARDO G. 2008. The medicinal mushroom Agaricus blazei Murrill: review of literature and pharmaco-toxicological problems. Evid Based Complement Alternat Med 5: 3-15.

GRIFFIN DH. 1994. Fungal physiology, $2^{\text {nd }}$ ed., New York: Wiley-Liss, 468 p. HAMEDI A, VAHID HAND GHANATI F. 2007. Optimization of the medium composition for production of mycelial biomass and exopolysaccharide by Agaricus blazei Murill DPPH 131 using response-surface methodology. Biotechnology 6: 456-464.

JUMES FMD, LUGARINI D, PEREIRA ALB, CHRISTOFF AO, LINDE GA, VALLE JS, COLAUTO NB AND ACCO A. 2010. Effects of Agaricus brasiliensis mushroom in Walker-256 tumor-bearing rats. Can J Physiol Pharmacol 88: 21-27.

KERRIGAN RW. 2005. Agaricus subrufescens, a cultivated edible and medicinal mushroom, and its synonyms. Mycologia 97: 12-24.

KIM HH, NA JG, CHUN GT, CHANG YK, LEE SJ AND JEONG YH. 2004. Optimization of submerged culture conditions for mycelial growth and exopolysaccharides production by Agaricus blazei. J Microbiol Biotechnol 14: 944-951.

LIN JH AND YANG SS. 2006. Mycelium and polysaccharide production of Agaricus blazei Murrill by submerged fermentation. J Microbiol Immunol Infect 39: 98-108.

MEYER DJ, COLES HE AND RICH JL. 1992. Veterinary laboratory medicine: interpretation and diagnosis, $1^{\text {st }}$ ed., Philadelphia: WB Saunders, $350 \mathrm{p}$.

MIZUNO M, MINATO K, ITO H, KAWADE M, TERAI H AND TSUCHIDA. 1999. Anti-tumor polysaccharide from the mycelium of liquid-cultured Agaricus blazei mill. Biochem Mol Biol Int 47: 707-714.

MOURÃO F, LINDE GA, MESSA V, CUNHA JÚNIOR PL, EIRA AF AND COLAUTO NB. 2009. Antineoplasic activity of Agaricus brasiliensis basidiocarps on different maturation phases. Braz J Microbiol 40: 901-905.

MOURÃO F, UMEO SH, BERTÉLI MBD, LOURENÇO EL, GASPAROTTO A AND TAKEMURA OS. 2011a. Anti-inflammatory activity of Agaricus blazei in different basidiocarp maturation phases. Food Agric Immunol 22: 325-333.

MOURÃO F, UMEO SH, TAKEMURA OS, LINDE GA, TAKEMURA OS AND COLAUTO NB. 2011b. Antioxidant activity of Agaricus brasiliensis basidiocarps on different maturation phases. Braz J Microbiol 42: 197-202.

PONTE MF, TARGINO TS, MOTA MA AND LANDIM JS. 2012. Growth inhibition of Walker carcinosarcoma 256 with alcoholic extract of green tea leaves (Camellia sinensis). Acta Cir Bras 27: 634-638.

PONTECORVO G, ROPER JA, HEMMONS LM, MCDONALD KD, MCDONALD KD AND BUFTON AWJ. 1953. The genetics of Aspergillus nidulans. Adv Genet 5: 141-238.

RAMBERG JE, NELSON ED AND SINNOTT RA. 2010. Immunomodulatory dietary polysaccharides: a systemic review of the literature. Nutr J 9: 54-76.

SHIRAI M, IZUMI H AND YAMAGAMI T. 1991. Experimental transplantation models of mouse Sarcoma 180 mice for evaluation of anti-tumour drugs. J Vet Med Sci 53: 707-713.

THRALL MA, WEISER G, ALLISON R AND CAMPBELL TW. 2012. Veterinary hematology and clinical chemistry, $2^{\text {nd }}$ ed., Oxford: Wiley-Blackwell, 776 p.

WASSER SP. 2011. Current findings, future trends, and unsolved problems in studies of medicinal mushrooms. Appl Microbiol Biotechnol 89: 1323-1332.

WASSER SP, DIDUKH MY, AMAZONAS MAL, NEVO E, STAMETS P AND EIRA AF. 2002. Is a widely cultivated culinary-medicinal royal sun Agaricus (the himematsutake mushroom) indeed Agaricus blazei Murrill? Int J Med Mushrooms 4: 267-290.

ZHANG M, CUI SW, CHEUNG PCK AND WANG Q. 2007. Antitumor polysaccharides from mushrooms: a review on their isolation process, structural characteristics and antitumor activity. Trends Food Sci Technol 18: 4-19. 